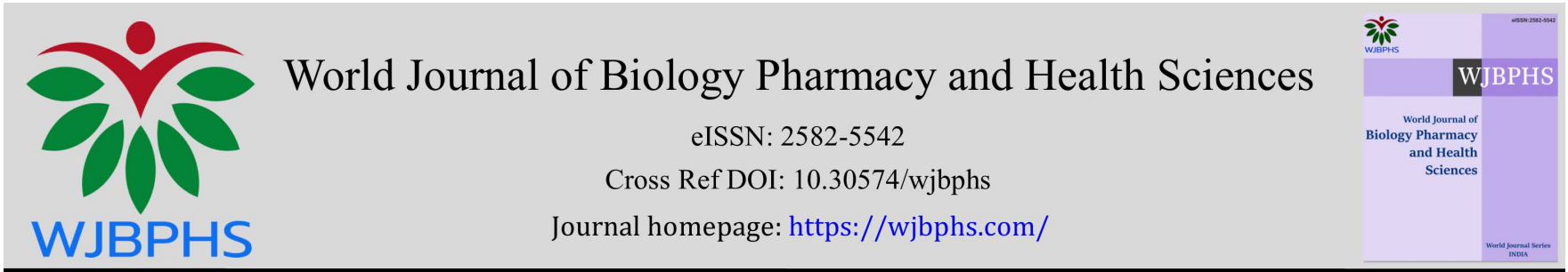

(RESEARCH ARTICLE)

\title{
Multidrug-resistant bacteria isolated from automated teller machine in metropolitan area of São Paulo, Brazil
}

\author{
Simone Aquino ${ }^{1,}{ }^{*}$, José Eduardo Alves de Lima ${ }^{2}$, Moisés Oliveira da Silva ${ }^{2}$, Gabriela Fabricio de Sousa ${ }^{2}$ \\ ${ }^{1}$ Instituto de Pesquisas Energéticas e Nucleares. Centro de Tecnologia das Radiações. Avenida Lineu Prestes, 2242 - \\ Cidade Universitária. São Paulo, SP - CEP 05508-000. Brazil. \\ 2 Universidade Nove de Julho. Departamento de Saúde II. Av. Dr. Adolpho Pinto, 109. São Paulo - SP - CEP 01156-050, \\ Brazil.
}

World Journal of Biology Pharmacy and Health Sciences, 2021, 05(01), 027-036

Publication history: Received on 03 January 2021; revised on 10 January 2021; accepted on 12 January 2021

Article DOI: https://doi.org/10.30574/wjbphs.2021.5.1.0002

\begin{abstract}
The aim of this study was to investigate bacterial contamination on surfaces of randomly selected Automated Teller Machine and their sensitivity to antibiotics in São Paulo city, Brazil. The swabs collected aseptically were inoculated in selective and non-selective media in triplicate and incubated at $37^{\circ} \mathrm{C}$ for $24 \mathrm{~h}$. After Gram staining the isolated colonies, complementary biochemical tests were applied. The antibiotic sensitivity pattern of all isolates (15 Gram-positive bacteria and 7 Gram-negative bacteria) was determined using the Kirk Bauer method using chloramphenicol, clindamycin, norfloxacin, erythromycin, gentamicin and tetracycline diffusion discs. All ATM surfaces tested were contaminated with at least one genus of bacteria. The most frequently isolated bacteria were Staphylococcus aureus (64\%), Enterococcus spp. (28\%) and Acinetobacter spp. (21\%), followed by coagulase-negative staphylococci (14\%), Pseudomonas spp. in 12 (14\%), Salmonella spp. (7\%), Escherichia coli (7\%). ATMs in the São Paulo metropolitan region were shown to be contaminated with bacteria that are resistant to the commonly used antibiotics. All Gram-negative and Gram-positive bacteria isolated were multidrug-resistant, however, the strains were sensitive (S) or showed an intermediate response profile (I) to tetracycline, with the exception of three strains of Pseudomonas spp., Acinetobacter spp. and Staphylococcus aureus, which were resistant to tetracycline. Norfloxacin and gentamicin showed resistance response profile to all bacteria. Based on these findings, it is recommended to perform hand washing and use of antiseptics after using ATMs.
\end{abstract}

Keywords: Automated Teller Machine; Bacteria; Multidrug-resistant; Antibiotics

\section{Introduction}

Fomites are inanimate objects capable of transmitting infectious microorganisms. Most pathogens are able to survive on surfaces and these surfaces can act as sources of pathogen transmission if no disinfection is performed [1]. This theme gained greater notoriety after the Covid-19 pandemic and efforts to study contaminated surfaces with the virus have been ongoing since the outbreak beginning. Coronavirus can sustain for a long time on various surfaces which is a major reason for its transmission, because this virus can last for long durations on different plastic or metal surfaces, ranging from hours to days [2]. The two important coronaviruses (SARS-CoV-2 and SARS-CoV-1) have significant sustaining time on different metal surfaces, and their behaviour is almost similar on various metal surfaces and in aerosols $[3,4]$.

\footnotetext{
${ }^{*}$ Corresponding author: Simone Aquino

Instituto de Pesquisas Energéticas e Nucleares. Centro de Tecnologia das Radiações. Avenida Lineu Prestes, 2242 - Cidade Universitária. São Paulo, SP - CEP 05508-000. Brazil. E-mail: siaq06@hotmail.com 
In addition, the survival of nosocomial pathogens such as bacteria, including methicillin-resistant Staphylococcus aureus (MRSA), in the environment has been of great interest to infection control professionals for years [5]. The Automated Teller Machine (ATM) has been an important device in the banking sector and other financial institutions. The ATM is a computerized telecommunication device which makes banking easier today [6]. As helpful as ATM machine is, recently id biometric has been identified to have a detrimental effect on the health of its users, as it is now a source of infection to the users. Bacteriological examinations were carried out on cash dispensing machine because the ATMs are likely to be contaminated with various microorganisms due to many users per day [7].

The keypads of 74 ATMs were examined by Iquo and colleagues [8] in Calabar Metropolis to determine the public health implications of microorganisms isolated from the machines and their potentials as reservoirs of microbes. The authors reported that fifty-two (70.3\%) of the ATMs were contaminated with various microbial pathogens (bacteria and fungi). The ATMs is likely to be contaminated with various microorganisms due to their vast dermal contact by multiple users. Many authors examined the metallic keypads of ATMs to investigate their potentials as source of bacterial contamination and also the antibiogram of the isolated organisms, around the world [9-13]. The objective of the present study was to evaluate the bacterial contamination of the biometric system of ATMs located in the city of São Paulo (Brazil) and to investigate the susceptibility profile of twenty-two isolated strains to antibiotics.

\section{Material and methods}

\subsection{Sample location}

The samples $(n=14)$ were collected in the period of January 2017 to March 2018, from 14 different commercial banks situated in São Paulo city in South hemisphere (latitude -23.533773 and longitude -46.625290) in Brazil. In order to collect the samples, it was used sterile cotton swab sticks moistened with sterile physiological saline before swabbing the biometric fingerprint buttons of the ATM machines. All cotton swab sticks were immediately transported in sterile tubes and transferred to the microbiology laboratory for analysis, in a refrigerated box and analyzed within 24 hours.

\subsection{Isolation of bacteria}

The swabs (2 for each ATM digital surface) were inoculated onto nonselective media for bacteria (Nutrient agar and Blood agar) and selective medium in triplicate plates and incubated at $37^{\circ} \mathrm{C}$ for $24 \mathrm{~h}$. Bacterial identification of single colonies grown or colony-forming units (CFU) on MacConkey, Nutrient and Blood agar plates were tested using Gram stain colonial morphology, to detect Gram-negative or Gram-positive bacteria. Gram-positives cocci were tested as catalase positive or negative. Most aerobic microorganisms possess the enzyme catalase which acts as a catalyst in the breakdown of hydrogen peroxide to oxygen and water [14]. Gram-positive cocci include Staphylococcus (catalasepositive), which grows clusters and Streptococcus (catalase-negative), which grows in chains [15]. A selective media for Enterococcus and for $S$. aureus it was applied the Mannitol and Baird Parker media, to differentiate $S$. aureus from other coagulase-negative staphylococci.

The method of choice for isolation of $S$. aureus was the Baird Parker plate count and Mannitol Salt Agar (MSA). Mannitol salt agar (MSA) is a conventional medium that is frequently used to screen swab specimens for presumptive $S$. aureus based on the growth of yellow colonies derived from the fermentation of mannitol [16]. Baird Parker is a selective agar that contains sodium pyruvate, egg yolk emulsion, glycine and lithium chloride, which suppress the growth of most bacteria, without inhibiting $S$. aureus. Typical grey-black shiny colonies (formed by the potassium tellurite reduction) of $S$. aureus on this medium are 1-1.5 mm diameter, with an opaque halo surrounded by a 2-5 mm zone of clearing. The halo is a result of lipase activity and the clearing zone is due to proteolytic action [17].

\subsection{Biochemical tests}

The complementary biochemical tests for Gram-negative bacilli, it was applied the Rugai medium without sucrose, also known as the medium of Escola Paulista de Medicina (EPM), Mili test tube, Citrate agar and Triple Iron Sugar agar (TSIA). The EPM medium allows simultaneous execution six biochemical tests for the identification of enterobacteria: Deamination of L-tryptophan, Glucose, Gas production, production $\mathrm{H}_{2} \mathrm{~S}$ and urea hydrolysis. The EPM composition is: $\mathrm{L}$ Ammonium iron citrate (2 g); Sodium thiosulfate (2 g); Dextrose (10 g); Urea (40 g); Nutrients (23 g); Agar (11 g); Sodium chloride (5 g); Disodium phosphate ( $2 \mathrm{~g})$; L - tryptophan ( $1 \mathrm{~g})$; Bromothymol blue $(0.03 \mathrm{~g})$; Deionized water $(1000 \mathrm{~mL})$ and $\mathrm{pH} 7.4( \pm 0.2)$ to $25^{\circ} \mathrm{o}$ [18].

MIL (motility, indole, lysine) medium is used to differentiate Enterobacteriaceae on the basis of motility, indole production, lysine-decarboxylation and lysine-deamination. MIL media, when used in conjunction with TSIA or EPM agar provide the necessary information for the presumptive identification of the enteric pathogens within the family 
Enterobacteriaceae [19]. An inoculum from an 18-24 hour isolate in pure culture is used by an inoculating needle stab the medium to within one half inch from the bottom of the tube. After to incubate aerobically at 35ㄷ. for 18-24 hours, read lysine and motility prior to the addition of Kovacs reagent. Growth away from the stab line is a positive test for motility and only along the stab line is a negative test. A positive test for lysine-decarboxylase is a purple band and a purple butt. A negative test is a narrow purple band and a yellow butt. A positive test for lysine-deamination is a deep red band with a yellow butt. A negative test is a purple band with a yellow butt. After the addition of 3-4 drops of Kovacs reagent (which contain $4(\mathrm{p})$-dimethylaminobenzaldehyde) an indole reaction positive is a pink layer of reagent. In contrast, a yellow layer is considered negative [20].

Citrate utilization test was carried out to determine some of the isolates that have the ability to utilize citrate as its only source of carbon for its metabolism. The citrate permease produced by the citrate utilizing organisms facilitates the transport of the citrate into the cell, thereby enabling the organism to utilize it as the sole carbon source. The isolates were inoculated into slope of the test tubes; a positive result was indicated by a colour change from green to bright blue after 48 hours of incubation [10].

The TSIA test is designed to differentiate among the different groups or genera of the Enterobacteriaceae, which are all Gram-negative bacilli capable of fermenting glucose with the production of acid, and to distinguish them from other Gram-negative intestinal bacilli. The differentiation is based on fermentation of glucose and lactose or sucrose and hydrogen sulfide $\left(\mathrm{H}_{2} \mathrm{~S}\right)$ production. TSIA medium contains 10 parts of lactose: 10 parts of sucrose: 1 part of glucose and peptone. Phenol red and ferrous sulfate serve as indicators of acidification and $\mathrm{H}_{2} \mathrm{~S}$ formation, respectively. The acid base indicator phenol red incorporated for detecting carbohydrate fermentation is indicated by the change in color of the carbohydrate medium from orange red to yellow in the presence of acids. In case of oxidative decarboxylation of peptone, alkaline products are built and the $\mathrm{pH}$ rises. This is indicated by the change in color of the medium from orange red to deep red. Sodium thiosulfate and ferrous ammonium sulfate present in the medium detects the production of hydrogen sulfide and is indicated by the black color in the butt of the tube. The oxidase test was used to identify Pseudomonas spp. which produces the cytochrome oxidase enzymes. A colony from pure culture was smeared on a portion of the oxidase strip (Oxoid® UK) using an inoculating loop. After 10 seconds, a dark purple coloration indicates a positive result $[21,22]$.

\subsection{Antibiotic susceptibility testing}

Antibiotics were chosen according to the different classes of antimicrobial agents, such as chloramphenicol, clindamycin, norfloxacin, erythromycin, gentamycin and tetracycline. The isolates were tested in duplicate for antimicrobial susceptibility using Kirby Bauer agar disc diffusion method [23]. The test medium for diffusion disc (Sensidisc DME $\circledR$ ) was Mueller Hinton Agar (MHA) and the inoculum suspension was performed directly from the $24 \mathrm{~h}$ growth colony, equivalent to the 0.5 MacFarland scale. Incubation temperature of $35( \pm 2){ }^{\circ} \mathrm{C}$, for 18 hours. The diameter of the zones of inhibition surrounding the antimicrobial disc was measured to the nearest mm. Isolates were deemed resistant only when the zones of inhibition was less or equal to the resistance breakpoint recommended by the Clinical and Laboratory Standards Institute [24]. Each isolate was classified as sensitive (S), intermediate (I) or resistant (R) according to the CLSI [24]. Isolates exhibiting resistance to, at least, two of the antimicrobial agents of different classes were considered as multi-resistant strains. The diameter limit of the inhibition zone for each strain according to the type of antibiotic was based on the ranges was determined according to the Kirby-Bauer disk diffusion susceptibility test protocol $[25,26]$.

\section{Results}

\subsection{Prevalence of Gram-positive and Gram-negative in ATMs}

All the samples $(n=14)$ were contaminated with Gram-positive and Gram-negative bacteria. The total percentage for Staphylococcus aureus and Enterococcus spp. demonstrated the highest occurrence among Gram-positive bacteria. Most of the Gram-negative group was represented by Acinetobacter spp. and Pseudomonas spp., followed by Escherichia coli and Salmonella spp. in a smaller percentage. A total of twenty-two strains were identified in the keypads of different ATMs (Table 1).

The hand borne transmission through ATM is one of the most important routes for the spread of infectious agents in the community. ATMs can serve as potential vectors for transmission of infection [27]. The data from the present study demonstrated that the evaluated ATMs are subject to contamination by pathogenic bacteria, as occurs in other countries. A study carried out by Barbosa et al. [12] in the Metropolitan Area of Porto (Portugal) showed that 50 ATMs were contaminated with Enterobacteriaceae, E. coli, Enterococci, Staphylococcus coagulase positive and Listeria spp. 
Adedoyin [28] (2019) investigated the bacterial colonization on ATMs in Ibadan metropolis, in Nigeria. The author reported that the prevalence of bacteria found on the ATMs were 51.8\% Staphylococcus aureus, 39.7\% Lactose fermenters, 22\% Streptococcus spp., 20.5\% Pseudomonas spp., and 10.8\% Coagulase negative Staphylococcus spp.

Table 1 Frequency of bacteria genera (Gram-positive and Gram-negative) in 14 ATMs.

\begin{tabular}{|l|l|l|l|}
\hline Gram & Microorganism & $\begin{array}{l}\text { Number of } \\
\text { contaminated ATMs }\end{array}$ & Frequency (\%) \\
\hline \multirow{4}{*}{ Positive } & Staphylococcus aureus & 9 & 64.28 \\
\cline { 2 - 4 } & Enterococcus spp. & 4 & 28.57 \\
\cline { 2 - 4 } & Staphylococcus (CoNS) & 2 & 14.28 \\
\hline \multirow{4}{*}{ Negative } & Acinetobacter spp. & 3 & 21.42 \\
\cline { 2 - 4 } & Pseudomonas spp. & 2 & 14.28 \\
\cline { 2 - 4 } & Salmonella spp. & 1 & 7.14 \\
\cline { 2 - 4 } & Escherichia coli & 1 & 7.14 \\
\hline
\end{tabular}

According to Elfakey [29], the ATMs in Khartoum State (Sudan) are likely to be contaminated with various microorganisms due to multiple users. The isolates found in 60 ATMs investigated included 58.6\% Bacillus spp., 10.34\% Klebsiella spp., 6.89\% Escherichia spp., 2.59\% Enterobacter spp., 7.75\% Staphylococcus spp., 2.59\% Streptococcus spp., $1.72 \%$ Micrococcus luteus, $1.72 \%$ Proteus spp., 1.72\% Hafnia alvei, 1.72\% Acinetobacter calcoaceticus, 0.86\% Salmonella paratyphi and 0.86\% Pseudomonas spp. Osarenmwinda and Blessing [30] studied ATMs in Nigeria and reported 23\% of Bacillus spp., 21\%, Staphylococcus aureus, 19\% Eschericihia coli, 11\% Klebsiella pneumonia, Coagulase negative Staphylococcus and Pseudomonas aeruginosa was 9\% respectively, Proteus spp. with occurrence of $8 \%$.

\subsection{Identification of Gram-positive isolates and Antibiotics Susceptibility Test}

Fifteen strains of Gram-positive bacteria were isolated from ATMs. The frequency in samples was $60 \%$ S. aureus, $26.6 \%$ Enterococcus spp. and 13.33\% Staphylococcus spp. This study is also in conformity with Mbajiuka [6] who reported that Staphylococcus aureus were prevalent on species on the keyboards of ATM machines, in Nigeria (82.5\%). The characteristics of the isolates are shown in Table 2.

Table 2 Results of the Gram-positive bacteria from ATMs

\begin{tabular}{|c|c|c|c|c|c|c|}
\hline Sample & Bacteria & $\begin{array}{l}\text { Morpholo } \\
\text { gy/ Gram }\end{array}$ & $\begin{array}{l}\text { Hemolysis on Blood } \\
\text { agar }\end{array}$ & $\begin{array}{l}\text { Catalase/ } \\
\text { coagulase }\end{array}$ & $\begin{array}{l}\text { Mannito } \\
\text { l }\end{array}$ & $\begin{array}{l}\text { Baird- } \\
\text { Parker }\end{array}$ \\
\hline 1 & S. aureus & Cocci G+ & alpha & $+/+$ & + & + \\
\hline 2 & S. aureus. & Cocci G+ & alpha & $+/+$ & + & + \\
\hline 3 & S. aureus & Cocci G+ & alpha & $+/+$ & + & + \\
\hline 4 & S. aureus & Cocci G+ & alpha & $+/+$ & + & + \\
\hline 5 & Enterococcus spp. & Cocci G+ & gamma & $-/-$ & - & - \\
\hline 6 & S. aureus & Cocci G+ & alpha & $+/+$ & + & + \\
\hline 7 & S. aureus & Cocci G+ & alpha & $+/+$ & + & + \\
\hline 8 & S. aureus & Cocci G+ & alpha & $+/+$ & + & + \\
\hline 9 & S. aureus & Cocci G+ & alpha & $+/+$ & + & + \\
\hline 10 & Enterococcus spp. & Cocci G+ & gamma & $-/-$ & - & - \\
\hline 11 & Staphylococcus (CoNS) & Cocci G+ & beta & $+/-$ & - & - \\
\hline 12 & Enterococcus spp. & Cocci G+ & gamma & $-/-$ & - & - \\
\hline 13 & Enterococcus spp. & Cocci G+ & gamma & $-/-$ & - & - \\
\hline 14 & S. aureus & Cocci G+ & alpha & $+/+$ & + & + \\
\hline 15 & Staphylococcus (CoNS) & Cocci G+ & beta & $+/-$ & - & - \\
\hline
\end{tabular}


Staphylococcus aureus is the main pathogen of the group, responsible for a variety of clinical infections in humans and a leading cause of bacteremia, endocarditis, and many infections related to invasive medical devices [31]. According to Ansari and colleagues [32] S. aureus has been found to be associated with a high rate of health care-associated infections in hospitalized and immuno-compromised patients as well as community-acquired infections. Meanwhile, coagulase negative staphylococci (CoNS), especially $S$. epidermidis and $S$. haemolyticus, have emerged as recurrent causative agents of nosocomial infections, mainly those related to indwelling devices [33].

Enterococci are hardy, Gram-positive cocci that are common residents of the gastrointestinal tracts of nearly all land animals, including humans. While a core member of the microbiome, they are also capable of causing a variety of severe infections, most often among antibiotic-treated hospitalized patients with perturbed intestinal microbiota [34].

The increasing threat of antimicrobial resistance has shed light on the interconnection between humans, animals, the environment, and their roles in the exchange and spreading of resistance genes [35]. In recent years, antimicrobial resistance has become a major public health issue and methicillin-resistant $S$. aureus (MRSA) strains have developed resistance to all beta-lactam antibiotics including penicillin, cephalosporin, and carbapenem. The emergence of infections caused by drug-resistant bacteria is a serious and growing global health concern [32].

In the present study, the results of the antibiotic sensitivity test of Gram-positive stains isolated from ATMs demonstrated that all isolated were multi-drug resistance. The Table 3 shows the antibiotic sensitivity test result of the isolates.

Table 3 Results of the Antibiotic Sensitivity Testing of the Gram-positive bacteria.

\begin{tabular}{|c|c|c|c|c|c|c|c|}
\hline Sample & Microorganism & $\mathbf{N}$ & $\mathbf{C l}$ & $C$ & $\mathbf{E}$ & G & $\mathbf{T}$ \\
\hline 1 & S. aureus & $\mathrm{R}$ & $\mathrm{R}$ & $\mathrm{R}$ & $\mathrm{R}$ & $\mathrm{R}$ & $\mathrm{R}$ \\
\hline 2 & S. aureus. & $\mathrm{R}$ & $\mathrm{R}$ & S & I & $\mathrm{R}$ & S \\
\hline 3 & S. aureus & $\mathrm{R}$ & I & S & I & $\mathrm{R}$ & S \\
\hline 4 & S. aureus & $\mathrm{R}$ & $\mathrm{R}$ & S & S & $\mathrm{R}$ & S \\
\hline 5 & Enterococcus spp. & $\mathrm{R}$ & $\mathrm{R}$ & S & I & $\mathrm{R}$ & I \\
\hline 6 & S. aureus & $\mathrm{R}$ & $\mathrm{R}$ & $\mathrm{R}$ & I & $\mathrm{R}$ & S \\
\hline 7 & S. aureus & $\mathrm{R}$ & I & $\mathrm{R}$ & $\mathrm{R}$ & $\mathrm{R}$ & S \\
\hline 8 & S. aureus & $\mathrm{R}$ & $\mathrm{R}$ & $\mathrm{R}$ & I & $\mathrm{R}$ & I \\
\hline 9 & S. aureus & $\mathrm{R}$ & $\mathrm{R}$ & $\mathrm{R}$ & I & $\mathrm{R}$ & S \\
\hline 10 & Enterococcus spp. & $\mathrm{R}$ & $\mathrm{R}$ & I & I & $\mathrm{R}$ & I \\
\hline 11 & Staphylococcus (CoNS) & $\mathrm{R}$ & $\mathrm{R}$ & $\mathrm{R}$ & I & $\mathrm{R}$ & S \\
\hline 12 & Enterococcus spp. & $\mathrm{R}$ & $\mathrm{R}$ & $\mathrm{S}$ & I & I & I \\
\hline 13 & Enterococcus spp. & $\mathrm{R}$ & $\mathrm{R}$ & I & I & I & I \\
\hline 14 & S. aureus & $\mathrm{R}$ & $\mathrm{R}$ & $\mathrm{R}$ & I & $\mathrm{R}$ & I \\
\hline 15 & Staphylococcus (CoNS) & $\mathrm{R}$ & $\mathrm{R}$ & $S$ & I & $\mathrm{R}$ & I \\
\hline
\end{tabular}

N- Norfloxacin $10 \mu \mathrm{g}$; Cl- Clindamycin $2 \mu \mathrm{g}$; C - Chloramphenicol $30 \mu \mathrm{g}$; E - Erythromycin $15 \mu \mathrm{g}$; G - Gentamicin $10 \mu \mathrm{G}$ and T - Tetracycline $30 \mu \mathrm{G}$.

Norfloxacin showed the highest resistance (100\%) response profile among all the antibiotics tested against Grampositive strains, followed by clindamycin (86.66\%) and gentamycin (86.66\%), while chloramphenicol showed 46.66\%. Erythromycin and tetracycline showed the lowest resistance response profile among all the antibiotics tested (13.33 \% and $6.66 \%$, respectively).

Tetracycline showed the highest susceptible response profile among all the antibiotics tested against $S$. aureus $(\mathrm{S}=66.66 \%)$, followed by chloramphenicol $(\mathrm{S}=33.33 \%)$, while erythromycin showed the lowest susceptible response profile $(\mathrm{S}=11.11 \%)$ among all the antibiotics tested against $S$. aureus. Erythromycin showed the highest intermediate response $(\mathrm{I}=66.66 \%)$ followed by clindamycin and tetracycline, that showed the same intermediate response profile 
( $\mathrm{I}=22.22 \%$ ) among the entire antibiotics test against S. aureus. As demonstrated in table 3, S. aureus was $100 \%$ resistant against norfloxacin. Multi-drug-resistant $S$. aureus has been found to be one of the major organisms causing a wide range of infections which are associated with high morbidity and mortality worldwide [36].

However, we observed also that the coagulase negative staphylococci (CoNS) demonstrated 100\% resistant against norfloxacin, clindamycin, chloramphenicol and gentamicine. The Staphylococcus spp. strains were sensible for tetracycline in $50 \%$ of tests and intermediate in 50\%. For erythromycin the Kirk Bauer test showed 100\% intermediate response (I).

The results of norfloxacin and clindamycin for Enterococcus spp. tests showed 100\% R, while for erythromycin and tetracycline were 100\% I. The Enterococcus spp. strains were 50\% R and 50\% I for gentamycin and, finally, against chloramphenicol were $50 \%$ I and $50 \% \mathrm{~S}$.

\subsection{Identification and Antibiotics Susceptibility Test of Gram-negative bacteria}

The Gram-negative bacteria group were represented by Escherichia coli (14.28 \%), Salmonella spp. (14.28 \%), Pseudomonas spp. (28.57 \%) and Acinetobacter spp. (42.85 \%). The results of laboratory tests for identification were showed in Table 4.

Table 4 Results of the Gram-negative bacteria from ATMs

\begin{tabular}{|c|c|c|c|c|c|c|c|c|}
\hline Sample & Bacteria & $\begin{array}{l}\text { Morphology/ } \\
\text { Gram }\end{array}$ & EPM & Mili & Citr & TSI & MacConkey agar & Oxi \\
\hline 1 & Pseudomonas spp. & Bacilli G- & $\begin{array}{l}\text { Gli- } \\
\text { Urease - }\end{array}$ & $\begin{array}{l}\text { Indol - } \\
\text { Mot + } \\
\text { Desc - }\end{array}$ & + & - & $+/$ lac - & + \\
\hline 2 & Escherichia coli & Bacilli G- & $\begin{array}{l}\text { Gli + } \\
\mathrm{H}_{2} \mathrm{~S} \text { - } \\
\text { Urease - } \\
\text { L-TD - }\end{array}$ & $\begin{array}{l}\text { Indol + } \\
\text { Mot - }\end{array}$ & - & $\begin{array}{l}\text { Gli+ } \\
\text { Gas+ }\end{array}$ & $+/$ lac + & - \\
\hline 3 & Salmonella spp. & Bacilli G- & $\begin{array}{l}\text { Gli+ } \\
\mathrm{H}_{2} \mathrm{~S}+ \\
\text { Urease - }\end{array}$ & $\begin{array}{l}\text { Indol - } \\
\text { Mot + }\end{array}$ & + & $\begin{array}{l}\mathrm{Gli}+ \\
\mathrm{H}_{2} \mathrm{~S}+\end{array}$ & $+/$ lac - & - \\
\hline 4 & Acinetobacter spp. & Cocobacilli G- & $\begin{array}{l}\text { Gli- } \\
\text { Urease - }\end{array}$ & $\begin{array}{l}\text { Indol - } \\
\text { Mot - } \\
\text { Desc - }\end{array}$ & - & - & + / lac- & - \\
\hline 5 & Acinetobacter spp. & Cocobacilli G- & $\begin{array}{l}\text { Gli- } \\
\text { Urease - }\end{array}$ & $\begin{array}{l}\text { Indol + } \\
\text { Mot + }\end{array}$ & - & - & + / lac - & - \\
\hline 6 & Acinetobacter spp. & Cocobacilli G- & $\begin{array}{l}\text { Gli- } \\
\text { Urease - }\end{array}$ & $\begin{array}{l}\text { Indol + } \\
\text { Mot + }\end{array}$ & - & - & + / lac - & - \\
\hline 7 & Pseudomonas spp. & Bacilli G- & $\begin{array}{l}\text { Gli- } \\
\text { Urease - }\end{array}$ & $\begin{array}{l}\text { Indol - } \\
\text { Mot + } \\
\text { Desc - }\end{array}$ & + & - & $+/$ lac - & + \\
\hline
\end{tabular}

Pseudomonas spp. isolated from ATM 1 showed $100 \%$ of resistance against all antibiotics. The same bacteria isolated from ATM 7 were resistant (R) in clindamycin, erythromycin and gentamicin. An intermediate response profile (I) was observed against norfloxacin and chloramphenicol. Pseudomonas spp. showed susceptible only tetracycline among all antibiotics tested.

E. coli demonstrated resistance (R) against almost all antibiotics, except in tetracycline (S). Salmonella spp. was susceptible (S) in tetracycline, intermediate (I) in erythromycin and showed resistant (R) for all the rest. Acinetobacter spp. (isolated from ATM 6) showed resistance response profile against all antibiotics (100\% R). The Acinetobacter strain 
isolated from ATM 5 was susceptible (S) to chloramphenicol and tetracycline, but resistant (R) for norfloxacin, clindamycin, erithormycin and gentamycin. Acinetobacter strain of ATM 4 was susceptible against tetracycline, but resistant (R) in all Kirk-Bauer test (Table 5).

Table 5 Results of the Antibiotic Sensitivity Testing of the Gram-negative bacteria

\begin{tabular}{|l|l|l|l|l|l|l|l|}
\hline Sample & Microorganism & N & Cl & C & E & G & T \\
\hline 1 & Pseudomonas spp. & R & R & R & R & R & R \\
\hline 2 & Escherichia coli & R & R & R & R & R & S \\
\hline 3 & Salmonella spp. & R & R & R & I & R & S \\
\hline 4 & Acinetobacter spp. & R & R & R & R & R & S \\
\hline 5 & Acinetobacter spp. & R & R & S & R & R & S \\
\hline 6 & Acinetobacter spp. & R & R & R & R & R & R \\
\hline 7 & Pseudomonas spp. & I & R & I & R & R & S \\
\hline
\end{tabular}

Note: N- Norfloxacin $10 \mu \mathrm{g}$; Cl- Clindamycin $2 \mu \mathrm{g}$; C - Chloramphenicol $30 \mu \mathrm{g}$; E - Erythromycin $15 \mu \mathrm{g}$; G - Gentamicin $10 \mu \mathrm{G}$ and; T - Tetracycline 30 $\mu \mathrm{G}$

In general, the antibiotics clindamycin and gentamycin demonstrated the highest resistance response profile among all antibiotics (100\% R, respectively) tested against Gram-negative bacteria. Norfloxacin and erythromycin showed equally a resistance response profile (R $85.7 \%$ ), while chloramphenicol demonstrated a resistance response of $71.42 \%$ (R). Tetracycline showed the highest susceptible response (S 71.42\%).

\section{Discussion}

The present study demonstrated the presence of Staphylococcus aureus, Staphylococcus coagulase negative (CoNS), Enterococcus spp., Escherichia spp., Salmonella spp., Pseudomonas spp. and Acinetobacter spp. These microorganisms are all well documented for their high pathogenicity, causing infections and even death in some major outbreaks.

These results showed the presence of $S$. aureus and CoNS, as already described by Bik [37], that described S. aureus as the major components of the skin and nose microbiota, which probably explains its prevalence as an ATM contaminant, because $S$. aureus can survive long periods on inanimate objects. Adedoyin [28] showed that the ATMs were contaminated with different microorganisms with $S$. aureus being the most prevalent bacteria.

Staphylococcus aureus were the most commonly isolated on all studied ATMs surfaces, but even low levels of Salmonella spp. or Escherichia coli can easily be transferred from the fingers to another surface of human body. E. coli serovars has been implicated in major food or water borne disease outbreaks. Pseudomonas aeruginosa, Acinetobacter and Enterococcus spp. are known opportunistic pathogens in nosocomial infections.

All Gram-negative and Gram-positive bacteria isolated were multidrug-resistant (to at least two tested antibiotics) and norfloxacin and gentamicin showed a high level of resistance response to all bacteria. However, the strains were sensitive (S) or showed an intermediate response profile (I) to tetracycline, with the exception of three strains of Pseudomonas spp., Acinetobacter spp. and Staphylococcus aureus, which were resistant to tetracycline.

The ATMs are devices that represent an important reservoir for bacterial dissemination. ATMs are used daily by hundreds of people with different socio-economic status and hygiene levels. Human beings have a marked tendency to pick up microorganisms from environmental objects, and hands have been shown to play an important role in their transmission [39].

It has been observed that antibiotic susceptibility of bacterial isolates was multiple drug resistance for all strains. The data of present study are according to Barbosa [12], that reported the bacteria risk of spreading antibiotic-resistant bacteria through contact with ATM machines and should not be neglected, in terms of impact on public health. 


\section{Conclusion}

This study confirmed the presence of multi-drug resistant bacteria on ATM surfaces. The bacteria genera isolated were Staphylococcus, Enterococcus, Pseudomonas, Acinetobacter, Escherichia, and Salmonella. The most prevalent bacteria present on the ATMs were Staphylococcus aureus while E. coli and Salmonella spp. were the least prevalent. The result of the antibiotic test showed that chloramphenicol and tetracycline are drugs of choice for Gram-positive and tetracycline showed to be the drug of choice for Gram-negative bacteria. It was demonstrated that microbial contamination of ATM keypads may be a way of contamination of pathogenic bacteria, among users. The use of disinfectant on ATMs surfaces, such as alcohol 70\% is recommended to reduces the microorganisms to a level that is not harmful to health. Hand cleaning may reduce the spread of bacteria among users of the ATM.

\section{Compliance with ethical standards}

\section{Disclosure of conflict of interest}

The author has no conflict of interest to declare

\section{References}

[1] Angelakis E, Azhar EI, Bibi F, Yasir M, Al-Ghamdi AK, Ashshi AM, Elshemi AG, Raoult D. Paper money and coins as potential vectors of transmissible disease. Future Microbiology. 2014; 9(2): 249-261.

[2] Suman R, Javaid M, Haleem A, Vaishya R, Bahl S, Nandan D. Sustainability of coronavirus on different surfaces. Journal of Clinical and Experimental Hepatology. 2020; 10(4): 386-390.

[3] Nishiura H, Linton NM, Akhmetzhanov AR. Initial cluster of novel coronavirus (2019-nCoV) infections in Wuhan, China is consistent with substantial human-to-human transmission. Journal of Clinical Medicine. 2020; 9(2): 488491.

[4] Moriyama M, Hugentobler WJ, Iwasaki A. Seasonality of respiratory viral infections. Annual Review of Virology. 2020; 7: 83-101.

[5] Tolba O, Loughrey A, Goldsmith CE, Millar BC, Rooney PJ, Moore JE. Survival of epidemic strains of nosocomialand community-acquired methicillin-resistant Staphylococcus aureus on coins. American Journal of Infection Control. 2007; 35(5): 342-346.

[6] Mbajiuka CS. Isolation and identification of microorganisms associated with the use of Automated Teller Machine (ATM) in Michael Okpara University of Agriculture, Umudike (MOUAU) and its environs. World Journal of Pharmaceutical Research. 2015; 4(8): 85-89.

[7] Odeyemi AT, Sulaimon AM, Odunmbaku E, Afolabi IE. Bacteriological contamination of user interface of Automated Teller Machines (ATM) of banks in Ekiti State University, Ado-Ekiti. International Journal of Research Studies in Microbiology and Biotechnology. 2018; 4(3): 18-25.

[8] Iquo B, Otu-Bassey IB, Mbah M, Usang AI, Konlak DG and Daniel HB. Microbiological survey of Automated Teller Machines (ATM) in Calabar metropolis. International Journal of Development Research. 2015; 5(10): $5761-5765$.

[9] Nworie O, Mercy M, Chukwudi A, Oko I, Chukwudum SO, Agah VM, Ekuma UO. Antibiogram of bacteria isolated from Automated Teller Machines within Abakaliki Metropolis. American Journal of Infectious Diseases. 2012; 8(4): 168-174.

[10] Okoro N, Nkechinyere U, Orji JO, Eze E, Ezennia NMA, Nwali UN and Onu EN. Comparative study of the antibiogram of some bacteria isolated from Automated Teller Machine (ATM) keypads from Abakaliki and Afikpo in Ebonyi State. Indo American Journal of Pharmaceutical Sciences. 2017; 4(2): 439-449.

[11] Mahmoudi H, Arabestani MR, Alikhani MY, Sedighi I, Kohan HF, Molavi M. Antibiogram of bacteria isolated from automated teller machines in Hamadan, West Iran. GMS Hygiene and Infection Control. 2017; 12: 1-6.

[12] Barbosa, JIB, Albano, HCP, Silva, FF, Teixeira, PCM. Microbial contamination of main contact surfaces of Automated Teller Machines from Metropolitan Area of Porto. International Journal of Environmental Studies. 2019. 
[13] Joshaline MC, Subathra M, Shyamala M, Padma S, Rekha. Automated Teller Machine (ATM)- a "pathogen city" - a surveillance report from locations in and around Madurai city, Tamil Nadu, India. International Journal of Public Health Science. 2014; 3(1): 51-56.

[14] Bartholomew JW, Mittewer T. Guideline for Hand in health care settings: recommendations of healthcare infection control practices advisory committee and HICPAC/SHEA/APIC/IDSA hand hygiene task force. Infection Control and Hospital Epidemiology. 2008; 23: 3-40.

[15] Sizar O, Unakal CG. Gram-positive Bacteria. StatPearls Treasure Island (FL): StatPearls Publishing. 2020.

[16] Santos DCM, Costa TM, Rabello RF, Alves FA, Mondino SSB. Mannitol-negative methicillin-resistant Staphylococcus aureus from nasal swab specimens in Brazil. Brazilian Journal of Microbiology. 2015; 46(2): 531533.

[17] Silva WP, Destro MT, Landgraf M, Franco BDGM. Biochemical characteristics of typical and atypical Staphylococcus aureus in mastitic milk and environmental samples of Brazilian dairy farms. Brazilian Journal of Microbiology. 2000; 31: 103-106.

[18] Laborclin. Rugai without sucrose - EPM.

[19] Reller LB, Mirrett S. Motility-Indole-Lysine medium for presumptive identification of enteric pathogens of Enterobacteriaceae. Journal of Clinical Microbiology. 1975; 2(3): 247-252.

[20] Baron E, Peterson LR,Finegold. SM. Bailey \& Scott's Diagnostic Microbiology. 1994, 9th ed. Mosby, St. Louis, MO.

[21] Aryal S. Triple Sugar Iron Agar (TSIA) Test. Microbe Notes. 2018.

[22] MacFaddin, JF. Biochemical Tests for Identification of Medical Bacteria, 3rd Ed. Lippincott Williams \& Wilkins, Philadelphia PA. 2000; 98.

[23] Cheesbrough, M., 2006. District Laboratory Practice in Tropical Countries. 2nd Edn. Cambridge University Press, Cambridge, 440.

[24] Clinical and Laboratory Standards Institute, 2000. Performance Standard for Antimicrobial Disk Susceptibility Tests; Approved Standards. 9th Edn. NCCLS. 26.

[25] Hudzicki J. Kirby-Bauer Disk Diffusion Susceptibility Test Protocol. American Society for Microbiology. 2016; 123.

[26] Clinical and Laboratory Standards Institute (CLSI). Performance Standards for Antimicrobial Susceptibility Testing. 28th ed. CLSI supplement M100 (ISBN 1-56238-838-X [Print]; ISBN 1-56238-839-8 [Electronic]). Clinical and Laboratory Standards Institute, 950 West Valley Road, Suite 2500, Wayne, Pennsylvania 19087 USA, 2018.

[27] Opasola OA, Iyanda YA, Sawyerr HO, Adewoye SO, AbdulRahman H, Dauda KA, Onifade IA. Can antibiotic resistant bacteria occur in Automated Teller Machines in Ilorin Metropolis? International Journal of Innovative Biochemistry \& Microbiology Research. 2017; 5(4): 18-24.

[28] Adedoyin AB. A Study Investigating Bacterial Colonization on Automated Teller Machines in Ibadan Metropolis, South-West Nigeria. Acta Scientific Pharmaceutical Sciences. 2019; 3(6): 119-132.

[29] Elfakey REE. Bacterial Contamination on Automatic Teller Machine Keyboards and their Antibacterial Sensitivity in Khartoum State. Thesis. University of Khartoum, Sudan. 2015.

[30] Osarenmwinda 0, Blessing 00. Quantification, variability assessment of bacterial pollution and public health hazards linked to users of Automated Teller Machines in Ekpoma, Edo State-Nigeria. International Journal of Microbiology and Biotechnology. 2020; 5(1): 34-40.

[31] Tong SY, Davis JS, Eichenberger E, Holland TL, Fowler VG. Staphylococcus aureus infections: Epidemiology, pathophysiology, clinical manifestations, and management. Clinical Microbiology Reviews. 2015; 28: 603-661.

[32] Ansari S, Jha RK, Mishra SK, Tiwari BR, Asaad AM. Recent advances in Staphylococcus aureus infection: focus on vaccine development. Infection and Drug Resistance. 2019; 12: 1243-1255.

[33] Becker K, Heilmann C, Peters G. Coagulase-negative staphylococci. Clinical Microbiology Reviews. 2014; 27: 870926.

[34] Selleck EM, Tyne DV, Gilmore MS. Pathogenicity of Enterococci. Microbiology Spectrum. 2019; 7(4): 1-38. 
[35] Rossi CC, Monalessa Fábia Pereira MF, Giambiagi-deMarval M. Underrated Staphylococcus species and their role in antimicrobial resistance spreading. Genetics and Molecular Biology. 2020; 43(1).

[36] Keihanian F, Saeidinia A, Abbasi K, Keihanian F. Epidemiology of antibiotic resistance of blood culture in educational hospitals in Rasht, North of Iran. Infection and Drug Resistance. 2018; 11: 1723-1728.

[37] Bik HM, Maritz JM, Luong A, Shin H, Dominguez-Bello MG, Carlton JM. Microbial community patterns associated with automated teller machine keypads in New York City. Applied Environmental Science. 2017; 1: 1-18.

[38] Okoro N, Mercy M, Chukwudi A, Oko I, Chukwudum SO, Agah VM, Ekuma UO. Antibiogram of bacteria isolated from Automated Teller Machines within Abakaliki. American Journal of Infectious Diseases. 2012; 8: 168-174. 